\title{
NGHIÊN CỨU TÁC DỤNG KÍCH THÍCH MIẼ̃N DỊCH CỦA ĐÔNG TRÙNG HẠ THẢO BANIKHA TRÊN ĐỘNG VẠT THỰC NGHIẸM
}

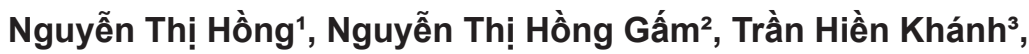 \\ Nguyễn Toàn Thiện Thắng ${ }^{3}$, Võ Thị Mỹ Hạnh ${ }^{3}$, Phạm Thị Vân Anh ${ }^{4}$ và Đinh Thị Thu Hằng4, \\ ${ }^{1}$ Công ty cổ phần Dược thảo Thiên Phúc

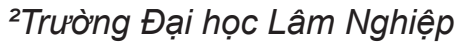

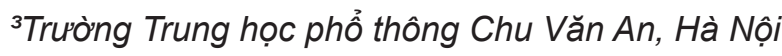 \\ ${ }^{4}$ Trường Đại học Y Hà Nội
}

Nghiên cứu được tiến hành nhằm đánh giá tác dụng kích thích miễn dịch của Đông trùng hạ thảo Bankikha trên động vật bị gây suy giảm miễn dịch bằng cyclophosphamid. Chuột nhắt được chia ngẫu nhiên vào 5 lô, mỗi lô 10 con: lô chứng sinh học, lô mô hình, lô chứng dương (levamisol) và Đông trùng hạ thảo Banikha liều $0,77 \mathrm{~g} / \mathrm{kg} / \mathrm{hgày}$ và $2,31 \mathrm{~g} / \mathrm{kg} / \mathrm{ng}$ ày. Chuột nhắt được tiêm màng bụng cyclophosphamid liều $200 \mathrm{mg} / \mathrm{kg}$ để gây suy giảm miễn dịch. Các chỉ số đánh giá gồm có trọng lượng lách và tuyến ức tương đối, số lượng bạch cầu chung ở máu ngoại vi, phản ứng bì với kháng nguyên $O A$, nồng độ IL-2, TNF- $\alpha$, IgM ở máu ngoại vi và giải phẫu bệnh vi thể lách và tuyến ức. Kết quả cho thấy Đông trùng hạ thảo Banikha liều 0,77 g/ $/ \mathrm{gg} /$ ngày có tác dụng kích thích miễn dịch rõ rệt; trong khi đó, Đông trùng hạ thảo Banikha liều 2,31 g/kg/ngày chỉ có xu hướng kích thích miễn dịch trên chuột nhắt trắng bị gây suy giảm miễn dịch bằng cyclophosphamid.

Từ khóa: Đông trùng hạ thảo Banikha, tác dụng kích thích miễn dịch, sự ức chế miễn dịch, cyclophosphamid.

\section{I. ĐẶT VẤN ĐÊ}

Miễn dịch học đang là một trong những lĩnh vực phát triển mạnh mẽ và có nhiều triển vọng của ngành công nghệ y sinh học. Một hướng nghiên cứu quan trọng và cấp thiết của miễn dịch là các vấn đề liên quan đến phòng ngừa và điều trị rối loạn chức năng miễn dịch: các bệnh lý suy giảm miễn dịch như viêm mạn tính, ung thư, các bệnh lý do tăng đáp ứng miễn dịch quá mức như bệnh tự miễn, bệnh hệ thống; ... ${ }^{1}$ Vì vậy, điều biến miễn dịch nhằm khôi phục lại sự cân bằng của hệ miễn dịch đang là mục tiêu của các thuốc và hóa chất hiện nay. Các

Tác giả liên hệ: Đinh Thị Thu Hằng

Trường Đại học Y Hà Nội

Email: dinhthuhang@hmu.edu.vn

Ngày nhận: 29/10/2020

Ngày được chấp nhận: 28/12/2020 chất điều biến miễn dịch được gọi là chất kích thích miễn dịch khi làm tăng cường hoạt động chức năng của các tế bào miễn dịch và ngược lại, nếu làm suy giảm hệ miễn dịch của cơ thể được gọi là chất ức chế miễn dịch. ${ }^{2}$

Dựa vào nguồn gốc, các chất kích thích miễn dịch được chia thành nhiều loại như cytokin tái tổ hợp (interleukin-2, các interferon...), các chất kích thích miễn dịch có nguồn gốc hóa chất (như levamisol, imuthiol), nguồn gốc vi sinh vật (như vaccin BCG) hay các chất có nguồn gốc từ thực vật (Hạ khô thảo, Hoàng bì, Nhàu...). ${ }^{3}$ Việc sử dụng các chất kích thích miễn dịch có nguồn gốc hóa học, được tổng hợp hoặc bán tổng hợp đem lại hiệu quả cao trong lâm sàng phòng và điều trị bệnh cũng như trong các nghiên cứu in vitro, in vivo. Các 
thuốc điều biến miễn dịch có nguồn gốc hóa học thường có nhiều tác dụng không mong muốn, các cytokin có chi phí cao trong quá trình điều trị. ${ }^{4}$ Các chất có nguồn gốc tự nhiên có ưu điểm hơn về giá thành cũng như an toàn hơn cho người sử dụng. Một số lượng lớn dược liệu và các chất phân lập đã được chứng minh là có tác dụng kích thích đáp ứng miễn dịch. ${ }^{5}$

Đông trùng hạ thảo Banikha là một chế phẩm được chiết xuất chủ yếu từ Đông trùng hạ thảo (Cordyceps militaris), ngoài ra còn có Nấm men, Linh chi và Hồng sâm. Hiệu quả hỗ trợ hệ miễn dịch khi dùng riêng rẽ Đông trùng hạ thảo, Nấm men, Linh chi và Hồng sâm đã được chứng minh trong nhiều y văn; ${ }^{5,6,7}$ tuy nhiên, cho đến nay chưa có công trình nghiên cứu đánh giá về tác dụng trên miễn dịch khi phối hợp các vị dược liệu này trên thế giới cũng như ở Việt Nam. Vì vậy, chúng tôi tiến hành nghiên cứu nhằm đánh giá tác dụng kích thích miễn dịch của Đông trùng hạ thảo Banikha trên chuột nhắt trắng bị gây suy giảm miễn dịch bằng cyclophosphamid.

\section{II. ĐỐl TƯƠ'NG VÀ PHƯO'NG PHÁP}

\section{Thuốc nghiên cứu}

Đông trùng hạ thảo Banikha: dạng viên nang (lọ 30 viên) được cung cấp bởi Công ty Cổ phần Dược thảo Thiên Phúc .

Thành phần: mỗi viên nang chứa 500 mg Đông trùng hạ thảo, $15 \mathrm{mg}$ chiết xuất Nấm men, 10 mg Linh chi và 10 mg Hồng sâm.

Liều dùng trên lâm sàng:

+ Người bình thường: uống mỗi lần 1 viên, ngày 2 lần.

+ Người bệnh: uống mỗi lần $2-3$ viên, ngày 2 lần.

\section{Hóa chất và dụng cụ xét nghiệm}

Cyclophosphamid (Endoxan) dạng thuốc bột của hãng Baxter, Đức. Levamisol (Tetramisole hydrocloride) dạng thuốc bột của hãng Sigma, Đức. Kit định lượng IL-2, TNF- $\alpha$ và IgM của hãng Cloud-Clone, Houston, Mỹ. Hoá chất và máy huyết học tự động Exigo-VET của hãng Exigo, Thụy Điển.

\section{3. Đối tượng}

Chuột nhắt trắng chủng Swiss, thuần chủng, cả 2 giống do Viện Vệ sinh dịch tễ Trung ương cung cấp. Chuột được nuôi trong điều kiện đầy đủ thức ăn và nước uống tại phòng thí nghiệm Bộ môn Dược lý, Trường Đại học $Y$ Hà Nội từ 7 ngày trước khi nghiên cứu và trong suốt thời gian nghiên cứu.

\section{Phương pháp}

Tiêm màng bụng cyclophosphamid, liều duy nhất 200 mg/kg thể trọng để gây suy giảm miễn dịch trên chuột nhắt trắng.

Chuột được chia ngẫu nhiên thành 6 lô:

Lô 1 ( $n=10$ )(Chứng sinh học): uống nước cất hàng ngày.

Lô 2 ( $n=10)$ (Mô hình): tiêm CY và uống nước cất hàng ngày.

Lô 3 ( $n=10)$ (Chứng dương): tiêm $C Y$ và uống levamisol liều 100 mg/kg.

Lô $4(n=10)$ (Đông trùng hạ thảo Banikha liều $0,77 \mathrm{~g} / \mathrm{kg} / \mathrm{ngày}$ ): tiêm $C Y$ và uống Đông trùng hạ thảo Banikha liều $0,77 \mathrm{~g} / \mathrm{kg} / \mathrm{ngày}$ (tương đương với liều dự kiến điều trị trên lâm sàng, hệ số ngoại suy là 12) .

Lô 5 ( $n=10)$ ( Đông trùng hạ thảo Banikha liều $2,31 \mathrm{~g} / \mathrm{kg} / \mathrm{ngày}$ ): tiêm $C Y$ và uống Đông trùng hạ thảo Banikha liều 2,31 $\mathrm{g} / \mathrm{kg} / \mathrm{ngày} \mathrm{(gấp}$ 3 lần liều dự kiến điều trị trên lâm sàng).

Levamisol và thuốc thử được pha mỗi ngày với dung môi là nước cất. Chuột bắt đầu được uống nước cất, levamisol và thuốc thử bằng kim đầu tù liên tục từ ngày thứ 1 đến ngày thứ 7 . Ngày thứ 4 của mô hình, tiêm màng bụng cyclophosphamid liều 200 mg/kg 
ở các lô $2,3,4,5$ và 6 .

Xét nghiệm chức năng miễn dịch: Trọng lượng lách, tuyến ức tương đối; xét nghiệm vi thể lách và tuyến ức; số lượng bạch cầu chung; phản ứng bì với kháng nguyên $\mathrm{OA}$; định lượng
IL-2, TNF- $\alpha$ và IgM ở máu ngoại vi.

\section{Xử lý số liệu}

Số liệu được xử lý bằng phần mềm Microsoft Excel 2007, kiểm định theo test T-Student. Kết quả được trình bày dưới dạng $\overline{\mathrm{X}} \pm \mathrm{SD}$.

\section{KÉT QUẢ}

\section{1. Ảnh hưởng của Đông trùng hạ thảo Banikha lên tình trạng chung của hệ miễn dịch}

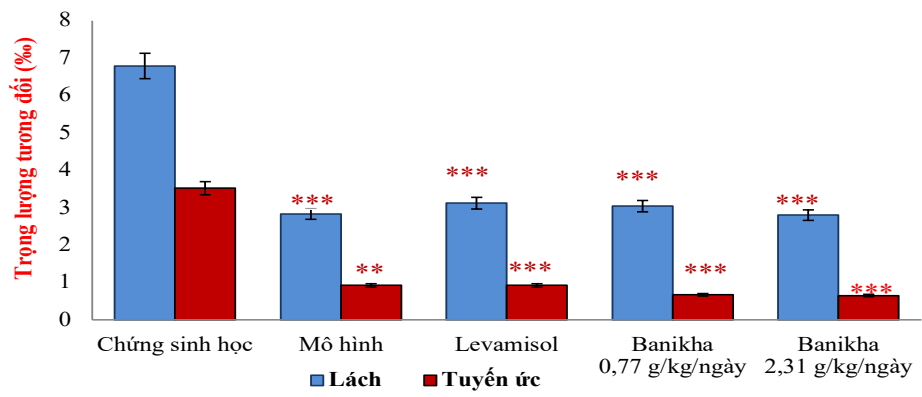

\section{Biểu đồ 1. Ảnh hưởng của Đông trùng hạ thảo Banikha lên trọng lượng lách và tuyến ức tương đối}

Chú thích: ${ }^{*}{ }^{* *},{ }^{* * *}$ : Khác biệt so với lô chứng sinh học với $p<0,05 ; p<0,01$ và $p<0,001$ $\Delta \Delta$ : Khác biệt so với lô mô hình với $p<0,01$

Banikha: Đông trùng hạ thảo Banikha

Kết quả ở biểu đồ 1 cho thấy: Ở lô mô hình, trọng lượng tuyến ức tương đối (TLTƯTĐ) và trọng lượng lách tương đối (TLLTĐ) giảm rõ rệt so với lô chứng sinh học $(p<0,001)$. Đông trùng hạ thảo Banikha liều $0,77 \mathrm{~g} / \mathrm{kg} / \mathrm{ngày} \mathrm{xu} \mathrm{hướng} \mathrm{tăng} \mathrm{TLLTĐ,} \mathrm{tuy} \mathrm{nhiên,} \mathrm{mức} \mathrm{liều} \mathrm{này} \mathrm{không} \mathrm{làm} \mathrm{thay} \mathrm{đổi}$ có ý nghĩa thống kê TLTƯTĐ so với lô mô hình. Đông trùng hạ thảo Banikha liều $2,31 \mathrm{~g} / \mathrm{kg} / \mathrm{ngày}$ không làm thay đổi có ý nghĩa thống kê TLTƯTĐ và TLLTĐ so với lô mô hình ( $p>0,05)$.

Cấu trúc vi thể của lách và tuyến ức

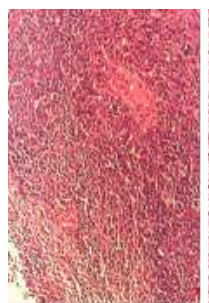

$\mathrm{CSH}$

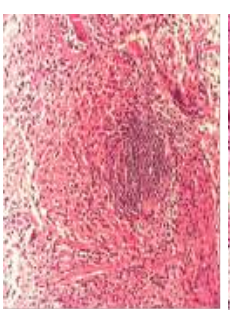

Mô hình

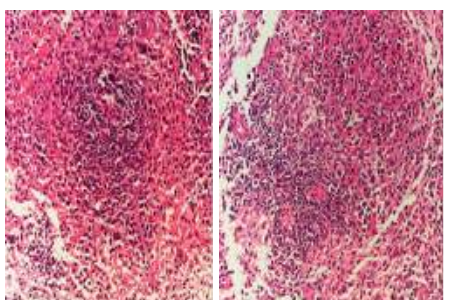

Levamisol Banikha $0,77 \mathrm{~g} / \mathrm{kg}$

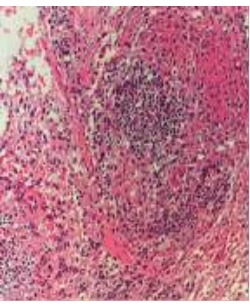

Banikha $2,31 \mathrm{~g} / \mathrm{kg}$

Hình 1. Hình ảnh vi thể lách $(\mathrm{HE} \times 40)$ 


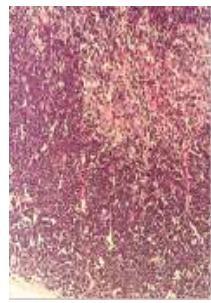

$\mathrm{CSH}$

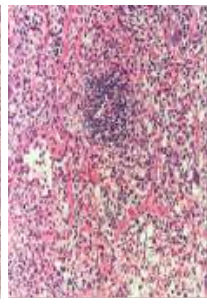

Mô hình

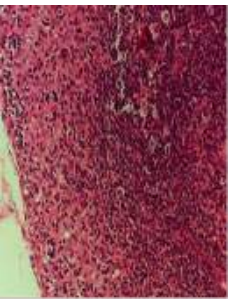

Levamisol

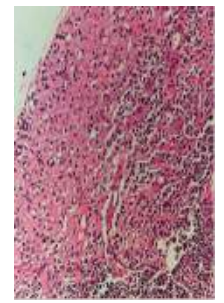

Banikha $0,77 \mathrm{~g} / \mathrm{kg} \quad$ Banikha $2,31 \mathrm{~g} / \mathrm{kg}$

Hình 2. Hình ảnh vi thể tuyến ức (HE × 40)

Ở lô mô hình, số lượng lympho bào, kích thước lách và tuyến ức giảm rõ rệt so với lô chứng sinh học. Đông trùng hạ thảo Banikha cả 2 liều $0,77 \mathrm{~g} / \mathrm{kg} / \mathrm{ngày}$ và liều $2,31 \mathrm{~g} / \mathrm{kg} / \mathrm{ngày} \mathrm{chưa} \mathrm{cải}$ thiện rõ rệt tổn thương gây ra do CY so với lô mô hình (Hình 1 và Hình 2).

Số lượng bạch cầu

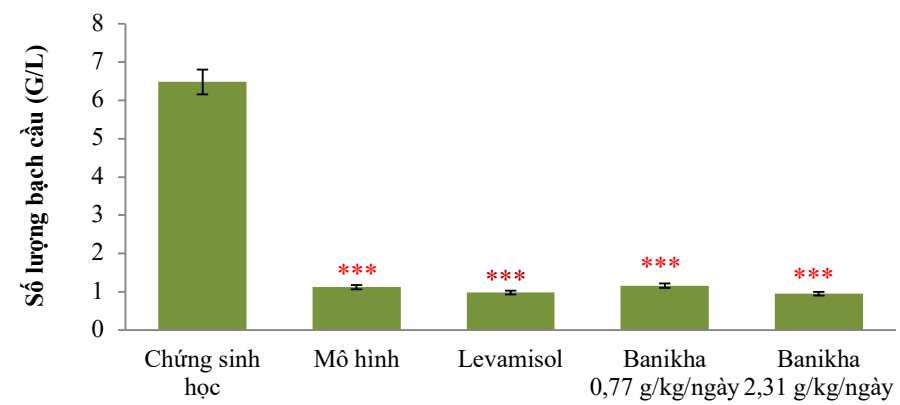

Biểu đồ 2. Ảnh hưởng của Đông trùng hạ thảo Banikha số lượng bạch cầu Chú thích: ***: Khác biệt so với lô chứng sinh học với $p<0,001$

Kết quả ở biểu đồ 2 cho thấy: Ở lô mô hình, tổng số lượng bạch cầu trong máu ngoại vi giảm rõ rệt so với lô chứng sinh học $(p<0,001)$. Ở lô dùng Đông trùng hạ thảo Banikha liều $0,77 \mathrm{~g} / \mathrm{kg} / \mathrm{ngày}$, số lượng bạch cầu trong máu ngoại vi có xu hướng tăng so với lô mô hình, tuy nhiên sự khác biệt không có ý nghĩa thống kê ( $p>0,05)$. Số lượng bạch cầu ở lô uống Đông trùng hạ thảo Banikha liều $2,31 \mathrm{~g} / \mathrm{kg} / \mathrm{ngày}$ không có sự khác biệt có ý nghĩa thống kê so với lô mô hình với $\mathrm{p}>0,05$.

\section{2. Ảnh hưởng của Đông trùng hạ thảo Banikha lên đáp ứng miễn dịch đặc hiệu}

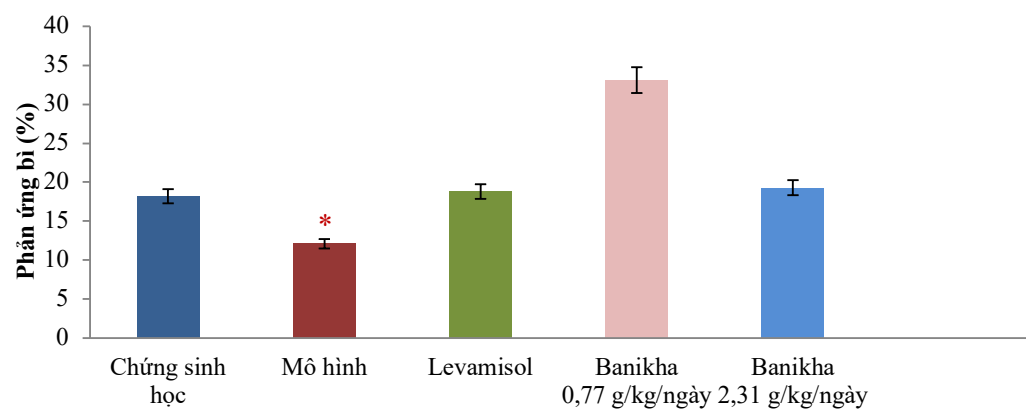

Biểu đồ 3. Ảnh hưởng của Đông trùng hạ thảo Banikha đến phản ứng bì với kháng nguyên $\mathrm{OA}$

Chú thích: *: Khác biệt so với lô chứng sinh học với $p<0,05$ 
Kết quả ở biểu đồ 3 cho thấy: Phản ứng bì với kháng nguyên OA ở lô mô hình giảm có ý nghĩa thống kê so với lô chứng sinh học với $p<0,05$. Đông trùng hạ thảo Banikha cả 2 liều $0,77 \mathrm{~g} / \mathrm{kg} / \mathrm{hgày}$ và $2,31 \mathrm{~g} / \mathrm{kg} / \mathrm{ngày}$ có xu hướng tăng phản ứng bì so với lô mô hình, tuy nhiên sự khác biệt không có ý nghĩa thống kê ( $p>0,05)$.

Định lượng các cytokin và kháng thể trong máu ngoại vi

Bảng 1. Ảnh hưởng của Đông trùng hạ thảo Banikha lên nồng độ một số cytokin (IL-2 và TNF- $\alpha$ ) và kháng thể IgM trong máu ngoại vi

\begin{tabular}{lccc}
\hline \multicolumn{1}{c}{ Lô } & $\begin{array}{c}\text { Nồng độ IL-2 } \\
(\mathbf{p g} / \mathbf{m L})\end{array}$ & $\begin{array}{c}\text { Nồng độ TNF- } \alpha \\
(\mathbf{p g} / \mathbf{m L})\end{array}$ & $\begin{array}{c}\text { Nồng độ IgM } \\
(\mathbf{m g} / \mathbf{m L})\end{array}$ \\
\hline Lô 1 (CSH) & $22,74 \pm 6,39$ & $30,37 \pm 8,45$ & $27,59 \pm 4,70$ \\
\hline Lô 2 (Mô hình) & $20,56 \pm 6,70$ & $25,80 \pm 6,61$ & $21,42 \pm 2,67^{* *}$ \\
\hline Lô 3 (levamisol) & $20,13 \pm 1,59$ & $42,77 \pm 18,28 \Delta$ & $22,06 \pm 3,51^{* *}$ \\
\hline $\begin{array}{l}\text { Lô } 4 \text { (Đông trùng hạ thảo } \\
\text { Banikha 0,77 g/kg/ngày) }\end{array}$ & $17,66 \pm 4,95$ & $41,89 \pm 11,42^{*} \Delta \Delta$ & $22,00 \pm 2,80^{* *}$ \\
\hline $\begin{array}{l}\text { Lô 5 (Đông trùng hạ thảo } \\
\text { Banikha 2,31 g/kg/ngày) }\end{array}$ & $18,52 \pm 2,15$ & $29,30 \pm 9,49$ & $23,13 \pm 2,41^{*}$ \\
\hline
\end{tabular}

Chú thích: *,**: Khác biệt so với lô chứng sinh học với $p<0,05$ và $p<0,01$

$\Delta, \Delta \Delta$ : Khác biệt so với lô mô hình với $p<0,05$ và $p<0,01$

Kết quả ở bảng 1 cho thấy: Ở lô mô hình, CY có xu hướng giảm nồng độ IL-2, TNF- $\alpha(p>0,05)$ và làm giảm rõ rệt nồng độ lgM $(p<0,01)$ trong máu ngoại vi so với lô chứng sinh học.

Đông trùng hạ thảo Banikha liều $0,77 \mathrm{~g} / \mathrm{kg} / \mathrm{ngày}$ làm tăng rõ rệt nồng độ $T N F-\alpha(p<0,01)$ và có xu hướng tăng IgM trong máu ngoại vi $(p>0,05)$; tuy nhiên, Đông trùng hạ thảo Banikha liều 0,77 g/kg/ngày không làm thay đổi có ý nghĩa thống kê nồng độ IL-2 so với lô mô hình.

Đông trùng hạ thảo Banikha liều $2,31 \mathrm{~g} / \mathrm{kg} / \mathrm{ngày} \mathrm{có} \mathrm{xu} \mathrm{hướng} \mathrm{làm} \mathrm{tăng} \mathrm{nồng} \mathrm{độ} \mathrm{TNF- \alpha} \mathrm{và} \mathrm{lgM}$ trong máu ngoại vi ( $p>0,05)$; tuy nhiên, Đông trùng hạ thảo Banikha liều $0,77 \mathrm{~g} / \mathrm{kg} / \mathrm{ngày} \mathrm{không}$ làm thay đổi có ý nghĩa thống kê nồng độ IL-2 so với lô mô hình.

\section{BÀN LUẬN}

Đa số các chất kích thích miễn dịch thể hiện rõ tác dụng trên hệ thống miễn dịch bị tổn thương hơn là hệ miễn dịch bình thường. Vì vậy, để nghiên cứu tác dụng kích thích miễn dịch của một chất, người ta thường tiến hành nghiên cứu trên hệ miễn dịch đã bị suy yếu. ${ }^{4}$

Cyclophosphamid (CY) là một tác nhân alkyl hóa kìm tế bào. CY ức chế sự phân chia của tất cả các tế bào đang tăng sinh (đặc biệt là các tế bào của tủy xương), do đó, trên miễn dịch, CY gây suy giảm cả đáp ứng miễn dịch dịch thể và miễn dịch qua trung gian tế bào. ${ }^{8}$ Do vậy, chúng tôi sử dụng $C Y$ làm chất gây suy giảm miễn dịch trên chuột nhắt trắng.

Levamisol là thuốc kích thích miễn dịch tác động trên cả miễn dịch dịch thể và miễn dịch qua trung gian tế bào, trong đó đáp ứng miễn dịch qua trung gian tế bào là mục tiêu chủ 
yếu của levamisol. Levamisol liều 100 mg/ kg được nhiều tác giả nghiên cứu và chứng minh hiệu quả kích thích miễn dịch rõ rệt. ${ }^{9}$

Lách là một tổ chức lympho ngoại vi lớn, là nơi trú ngụ của các lympho bào (chủ yếu là lympho bào $B$ ) và đại thực bào. Đây cũng là nơi tập trung kháng nguyên, nhất là các kháng nguyên vào cơ thể bằng đường máu. Sau khi xâm nhập và được đại thực bào xử lý, kháng nguyên sẽ kích thích các tế bào lympho $B$ tại lách phân chia, biệt hóa thành tương bào và sản xuất kháng thể để loại trừ kháng nguyên đó. Tuyến ức là cơ quan lympho trung ương, đảm nhiệm chức năng huấn luyện, phân chia và biệt hóa các tế bào lympho T. Tế bào lympho trong tuyến ức là từ tủy xương di cư tới. Tuyến ức đã tạo một vi môi trường thuận lợi để các tế bào lympho này biệt hóa thành dòng tế bào lympho T. ${ }^{10}$

Kết quả nghiên cứu cho thấy, ở lô mô hình, trọng lượng lách tương đối (TLLTÐ) và trọng lượng tuyến ức tương đối (TLTƯTĐ) của chuột nhắt trắng giảm rõ rệt so với lô chứng sinh học $(p<0,001)$. Ở lô dùng Đông trùng hạ thảo Banikha liều $0,77 \mathrm{~g} / \mathrm{kg} / \mathrm{ngày}$, TLLTÐ có xu hướng tăng so với lô mô hình, trong khi TLTƯTÐ không khác biệt so với lô mô hình. Ở lô dùng Đông trùng hạ thảo Banikha liều $2,31 \mathrm{~g} / \mathrm{kg} / \mathrm{ngày}$, TLLTÐ và TLTƯTĐ đều không khác biệt so với lô mô hình. Trên hình ảnh vi thể của lách và tuyến ức, không có sự cải thiện rõ rệt ở các lô dùng Đông trùng hạ thảo Banikha so với lô mô hình.

Số lượng bạch cầu trong máu ngoại vi là một chỉ số mang tính định lượng, phản ánh cả đáp ứng miễn dịch tự nhiên và miễn dịch đặc hiệu, là chỉ số huyết học phải được theo dõi chặt chẽ trên lâm sàng khi dùng $C Y$. Sự thay đổi số lượng bạch cầu trong máu ngoại vi phản ánh tác động của thuốc lên tế bào gốc tạo máu trong tủy xương. ${ }^{10}$ Kết quả nghiên cứu cho thấy, ở lô dùng Đông trùng hạ thảo Banikha liều $0,77 \mathrm{~g} / \mathrm{kg} / \mathrm{ngày}$, số lượng bạch cầu chung có xu hướng tăng so với lô mô hình. Tuy nhiên, ở lô dùng Đông trùng hạ thảo Banikha liều $2,31 \mathrm{~g} / \mathrm{kg} / \mathrm{ngày}$, số lượng bạch cầu chung không khác biệt so với lô mô hình.

Đáp ứng miễn dịch dịch thể là đáp ứng do các lympho bào $B$ đảm nhiệm. Sau khi nhận biết kháng nguyên, tế bào lympho $B$ sẽ tăng sinh và biệt hóa thành tương bào, bắt đầu sản xuất ra kháng thể. Các kháng thể này là kháng thể hòa tan, gọi một cách tổng quát hơn là các globulin miễn dịch (immunoglobulin, viết tắt là $\mathrm{Ig}$ ), đảm đương chức năng nhận biết, kết hợp đặc hiệu với kháng nguyên để gây hiện tượng tủa, ngưng kết và hoạt hóa hệ miễn dịch không đặc hiệu. Khi có kháng nguyên xâm nhập, IgM xuất hiện đầu tiên, $\lg G$ xuất hiện muộn hơn và sẽ thay thế cho IgM. Khi tiêm hồng cầu cừu cho chuột nhắt, các tế bào lympho $B$ sản xuất lgM ở lách được phát hiện từ ngày 2 đến ngày 6 sau khi tiêm kháng nguyên. ${ }^{10}$ Kết quả nghiên cứu của chúng tôi cho thấy ở lô mô hình (chỉ tiêm $\mathrm{CY}$ ), $\mathrm{CY}$ làm giảm rõ rệt nồng độ $\mathrm{lgM}$ trong máu ngoại vi so với lô chứng sinh học $(p<0,01)$. Kết quả nghiên cứu cho thấy nồng độ IgM trong máu ngoại vi của các lô uống Đông trùng hạ thảo Banikha có xu hướng tăng so với lô mô hình.

Bên cạnh đáp ứng miễn dịch dịch thể, đáp ứng miễn dịch qua trung gian tế bào là một phương thức đáp ứng đặc hiệu nhằm loại trừ kháng nguyên, do tế bào lympho $T$ phụ trách. ${ }^{10}$ Ovalbumin $(\mathrm{OA})$ là một protein kháng nguyên hình cầu phức tạp, phụ thuộc tuyến ức. Sau khi $O A$ được xử lý bởi các tế bào trình diện kháng nguyên, lympho bào $T$ có thể nhận biết, loại trừ trực tiếp $O A$ hoặc hỗ trợ tế bào lympho $B$ trong quá trình biệt hóa thành tương bào, tiết kháng thể. ${ }^{1}$ Đông trùng 
hạ thảo Banikha cả 2 liều đều có xu hướng làm tăng phản ứng bì so với lô mô hình.

Ngoài phản ứng bì với kháng nguyên $O A$, nồng độ cytokin trong máu cũng là chỉ số quan trọng để đánh giá đáp ứng miễn dịch qua trung gian tế bào. Trong nghiên cứu này, cytokin trong máu được lựa chọn là IL-2 và TNF- $\alpha .{ }^{11}$ IL-2 là một cytokin quan trọng, không thể thiếu trong đáp ứng miễn dịch đặc hiệu. IL-2 do Th tiết ra có vai trò kích thích, tạo dòng thác miễn dịch trong cơ thể. TNF- $\alpha$ còn có nhiều tác dụng sinh học khác trên đáp ứng miễn dịch qua trung gian tế bào như diệt tế bào mang kháng nguyên, hoạt hóa quá trình chết theo chu trình của tế bào nội mô, hoạt hóa đại thực bào, tham gia vào quá trình viêm, kích thích sự di chuyển của các tế bào miễn dịch tới vị trí viêm....12 Kết quả nghiên cứu cho thấy $C Y$ có xu hướng làm giảm nồng độ IL-2 và TNF-a so với lô chứng sinh học. Đông trùng hạ thảo Banikha cả 2 liều chưa cải thiện có ý nghĩa nồng độ IL-2 so với lô mô hình. Đối với nồng độ TNF- $\alpha$, chỉ có Đông trùng hạ thảo Banikha liều $0,77 \mathrm{~g} / \mathrm{kg} / \mathrm{ngày}$ có xu hướng làm tăng nồng độ TNF-a so với lô mô hình.

Hiện nay, trên thế giới đã có các báo cáo chứng minh tác dụng trên miễn dịch của Đông trùng hạ thảo trên thực nghiệm. Nghiên cứu của Shin S và cộng sự (2010) đã chứng minh tác dụng kích thích miễn dịch của Đông trùng hạ thảo thông qua làm tăng nồng độ của các cytokin tiền viêm, trong đó có TNF- $\alpha .^{13}$ Theo Shin JS và cộng sự (2018), trên chuột nhắt bị gây suy giảm miễn dịch bằng $\mathrm{CY}$, nấm Đông trùng hạ thảo dùng đường uống làm tăng sinh tế bào lách, tăng nồng độ của IL2, TNF- $\alpha$ và IL-10 trong máu ngoại vi. Trên nghiên cứu in vitro, nấm Đông trùng hạ thảo có tác dụng làm tăng sinh tế bào và tăng giải phóng cytokin từ tế bào tuyến ức. ${ }^{14}$ Theo LinZ
(2005), các polysaccharide trong Linh chi đã được chứng minh có tác dụng cải thiện chức năng của các tế bào trình diện kháng nguyen, cải thiện miễn dịch dịch thể và miễn dịch tế bào. ${ }^{15}$ Nghiên cứu của Gao J và cộng sự cho thấy Nấm men có tác dụng cải thiện đáp ứng miễn dịch dịch thể và miễn dịch tế bào. ${ }^{16}$ Tác dụng kích thích miễn dịch của Hồng sâm cũng được chứng minh trong các nghiên cứu in vitro và in vivo. ${ }^{17}$

\section{KÉT LUẬN}

Đông trùng hạ thảo Banikha liều $0,77 \mathrm{mg} /$ kg/ngày (tương đương với liều dự kiến điều trị trên lâm sàng) uống liên tục trong 7 ngày có tác dụng kích thích miễn dịch trên mô hình gây suy giảm miễn dịch cấp tính bằng cyclophosphamid thông qua tăng cường rõ rệt đáp ứng miễn dịch tế bào, xu hướng tăng cường đáp ứng miễn dịch dịch thể và xu hướng cải thiện chỉ số chung của hệ miễn dịch.

Đông trùng hạ thảo Banikha liều 2,31 g/ kg/ngày (gấp 3 lần liều tương đương với liều dự kiến điều trị trên lâm sàng) uống liên tục trong 7 ngày có xu hướng kích thích miễn dịch trên mô hình gây suy giảm miễn dịch cấp tính bằng cyclophosphamid thể hiện qua xu hướng tăng cường đáp ứng miễn dịch tế bào và xu hướng tăng cường đáp ứng miễn dịch dịch thể.

\section{TÀI LIẸU THAM KHẢO}

1. Katzung GB. Basic and Clinical Pharmacology, twelth edition, McGraw-Hill Companies, Inc. 2011.

2. Rang HP, Ritter JM, Flower RJ, Henderson G. Rang and Dale's pharmacology, eighth edition, Elsiver, UK. 2015.

3. Đào Văn Phan. Dược lý học lâm sàng, Trường Đại học $Y$ Hà Nội, Nhà xuất bản Y học, Hà Nội. 2018. 
4. Parnham MJ, Nijkamp FP. Principles of immunopharmacology, second edition. Birkhauser Verlag. 2005;377-389.

5. Đỗ Tất Lợi. Những cây thuốc và vị thuốc Việt Nam, Nhà xuất bản Y học, Hà Nội. 2015.

6. Jung S., Jung E., Choi E., Sin H., Ha K., Chae S. Immunomodulatory effects of a mycelium extract of Cordyceps (Paecilomyces hepiali; CBG-CS-2): a randomized and doubleblind clinical trial. BMC Complement Altern Med. 2019;19:77 .

7. Guangyu Xu, Guangxin Yuan, Liping An, Peige Du, Liya Xie, Hongyu Li, Yu Sheng, Xiao Han. Immunomodulatory mechanism of Cordyceps militaris polypeptide through regulating gene Hist1h2bp, Ctsg, and elane in mice. Pharmacognosy Magazine. 2018;14(56):404-410.

8. Shirani K, Hassani FV, RazaviAzarkhiavi K, Heidari S, Zanjani BR, Karimi G. Phytotrapy of cyclophosphamide-induced immunosuppression. Environ Toxicol Pharmacol. 2015;39(3):1262-1275.

9. Gupta M. Levamisole: A multi-faceted drug in dermatology. Indian J Dermatol Venereol Leprol. 2016;82(2):230-236.

10. Văn Đình Hoa. Sinh lý bệnh và miễn dịch, Phần Sinh lý bệnh học, Trường Đại học Y Hà Nội, Nhà xuất bản Y học, Hà Nội. 2019.

11. Cavalcanti YV, Brelaz MC, Neves JK, Ferraz JC, Pereira VR. Role of TNF-alpha,
IFN-gamma, and IL-10 in the development of pulmonary tuberculosis. Pulm Med. 2012;1-10.

12. Sirko $A$, Vaněk $T$, Góra-Sochacka A, Redkiewicz P. Recombinant Cytokines from Plants. Int J Mol Sci. 2011;12(6):3536-3552.

13. Shin S, Kwon J, Lee S, Kong H, Lee S, Lee CK, Cho K, Ha NJ, Kim K. Immunostimulatory Effects of Cordyceps militaris on Macrophages through the Enhanced Production of Cytokines via the Activation of NF-kappaB. Immune Netw. 2010;10(2):55-63.

14. Shin JS, Chung SH, Lee WS, Lee JY, Kim JL, Lee KT. Immunostimulatory effects of cordycepin-enriched WIB801CE from Cordyceps militaris in splenocytes and cyclophosphamide-induced immunosuppressed mice. Phytotherapy research. 2018;32:132-139.

15. Lin Z. Cellular and Molecular Mechanisms of Immuno-modulation by Ganoderma lucidum. J Pharmacol Sci. 2005;99:144 - 153.

16. Gao J, Zhang HJ, Yu SH, Wu SG, Yoon I, Quigley J, Gao YP, Qi GH. Effects of yeast culture in broiler diets on performance and immunomodulatory functions. Poult Sci. 2008; 87(7):1377-84.

17. Park SY, Kim HB, Kim JH, Lee JM, Kim SR, Shin HS, Yi TH. Immunostimulatory effect of fermented red ginseng in the mouse model. Prev Nutr Food Sci. 2014;19(1):10-8.. 


\section{Summary \\ EVALUATION OF THE IMMUNOSTIMULATORY ACTIVITY OF DONG TRUNG HA THAO BANIKHA IN EXPERIMENTAL ANIMALS}

The purpose of this study was to evaluate the immunostimulatory activity of Dong trung ha thao Banikha on animals immunosuppressed by cyclophosphamide (CY). Mice were divided randomly into 5 groups of 10 mice per cage: control, model, positive control (levamisole), Dong trung ha thao Banikha at the dose of $0.77 \mathrm{~g} / \mathrm{kg} /$ day and Dong trung ha thao Banikha at the dose of $2.31 \mathrm{~g} /$ $\mathrm{kg} /$ day. Immunosuppression on mice was induced by CY $200 \mathrm{mg} / \mathrm{kg}$ intraperitoneally. The indexes consisted of relative organ weight, leukocyte counts, OA induced paw edema, serum IL-2, TNF- $\alpha$ and IgM level and micro-histological images of spleen and thymus. As a result, Dong trung ha thao Banikha at the dose of $0.77 \mathrm{~g} / \mathrm{kg} /$ day significantly showed immunostimulatory influence; Dong trung ha thao Banikha at the dose of $2.31 \mathrm{~g} / \mathrm{kg} /$ day only had a tendency to ameliorate the effects of CY on immunosuppressive mice.

Keywords: Dong trung ha thao Banikha, immunostimulatory effect, immunosuppression, cyclophosphamide. 